KAROLINA CYRAN, OLGA KUREK-OCHMAŃSKA, DOMINIKA MAJ-SOLARZ, ANDRZEJ ROZMUS, MONIKA STRUCK-PEREGOŃCZYK

Wyższa Szkoła Informatyki i Zarzadzania $w$ Rzeszowie

\title{
MIĘDZY AUTONOMIĄ A URZĘDNICZYMI WYMAGANIAMI. PRAKTYKA DZIAEANIA TZW. RAM KWALIFIKACJI W WYBRANYCH UCZELNIACH EUROPEJSKICH. WYBRANE ASPEKTY ${ }^{1}$
}

\begin{abstract}
Cyran Karolina, Kurek-Ochmańska Olga, Maj-Solarz Dominika, Rozmus Andrzej, StruckPeregończyk Monika, Między autonomia a urzędniczymi wymaganiami. Praktyka działania tzw. ram kwalifikacji w wybranych uczelniach europejskich. Wybrane aspekty [Between Autonomy and Clerical Requirements. How the Qualification Framework Functions at Selected European Universities. Selected Aspects]. Studia Edukacyjne nr 37, 2015, Poznań 2015, pp. 135-152. Adam Mickiewicz University Press. ISBN 978-83-232-2967-4. ISSN 1233-6688. DOI: 10.14746/se.2015.37.9
\end{abstract}

For several years Polish universities have operated in new conditions defined by the National Qualification Framework. When it comes to implementing the Qualification Framework, Ireland, the United Kingdom, Germany, and France are regarded as the model countries. Many solutions applied by those countries can be treated as examples of good practice. Surveys conducted at the above mentioned universities showed that the key to the universities' teaching (and other) success is the appropriate balance between university autonomy and requirements of the regulatory institutions. In Poland there are autonomous universities on the one side and a great amount of clerical regulation caused by the implementation of the Qualification Framework on the other side. The experience of the surveyed universities from the United Kingdom, Ireland and Germany shows that the more freedom universities have in implementing the Qualification Framework, the more extensive the benefits.

Key words: university autonomy, National Qualification Framework, teaching framework, higher education

${ }^{1}$ Artykuł powstał w ramach projektu „Praktyka wdrażania Krajowych Ram Kwalifikacji w wybranych uczelniach europejskich. Społeczno-pedagogiczne uwarunkowania implementacji zmian w programach kształcenia studentów", prowadzonego w Wyższej Szkole Informatyki i Zarządzania, finansowanego w ramach badań statutowych Wydziału Administracji i Nauk Społecznych WSIiZ. 


\section{Wprowadzenie}

Informacje o konieczności wprowadzenia w European Higher Education Area „uniwersalnej struktury" 2 po raz pierwszy pojawiły się w oficjalnym komunikacie z Bergen w 2005 roku pt. „Osiągnięcie celów w Europejskim Obszarze Szkolnictwa Wyższego". Ministrowie szkolnictwa wyższego z poszczególnych krajów mieli ambicje, aby:

- po pierwsze, stworzyć możliwości porównywania kwalifikacji uzyskanych w różnych krajach, $\mathrm{w}$ tym „wdrożyć elastyczne ścieżki kształcenia oraz stworzyć możliwości uznawania efektów edukacji w innych formach niż oferowane w ramach zorganizowanego kształcenia na poziomie wyższym"3;

- po drugie, uwzględnić $\mathrm{w}$ procesie bolońskim perspektywę uczenia się przez całe życie;

- po trzecie wreszcie, zapewnić wysoki poziom kształcenia.

W Polsce konsekwencją programowych zmian w europejskim szkolnictwie wyższym było Rozporządzenie Ministra Nauki i Szkolnictwa Wyższego z 2 listopada 2011 r. w sprawie Krajowych Ram Kwalifikacji dla Szkolnictwa Wyższego (DzU 2011, 253, 1520). Od czasu wejścia w życie Rozporządzenia wszystkie uczelnie zostały zobowiązane do opisania programów studiów za pomocą efektów uczenia się, zawartych w trzech kategoriach: wiedzy, umiejętności i kompetencji społecznych.

Wprowadzenie KRK wzbudziło w polskim środowisku akademickim falę dyskusji. Krytyczne uwagi wskazują na m.in. na:

- biurokratyczny przymus tworzenia kart przedmiotów z uwzględnieniem wyżej opisanych efektów kształcenia, co pogwałca w opinii wielu akademików tradycyjną autonomię wykładowców i marginalizuje wieloletnie doświadczenia dydaktyczne;

- brak przeprowadzenia przez MNiSW badań i konsultacji w kwestii przyjętej koncepcji oraz brak ewaluacji nowego systemu, a co za tym idzie wprowadzenie urzędniczego, ministerialnego reżimu;

- „narzucenie zbyt szybkiego tempa prac, które utrudniało gruntowny namysł nad programami studiów" 4 ;

2 J.M. Pawlikowski, Wdrażanie programów kształcenia opracowanych zgodnie z założeniami KRK dla szkolnictwa wyższego, Seminarium bolońskie, http://ekspercibolonscy.org.pl/prez entacje?page=3, [dostęp: 10.10.2014].

3 J. Choromańska, Europejski Obszar Szkolnictwa Wyższego, http://www.uniaeuropejska. org/europejski-obszar-szkolnictwa-wyszego, [dostęp: 23.09.2014].

4 A. Wroczyńska, Jak wprowadzaliśmy KRK na Uniwersytecie Warszawskim, Forum Akademickie, 2013, 07-08. 
- problemy z mierzalnością kompetencji i umiejętności studentów, zwłaszcza w obszarze kompetencji społecznych;

- brak wsparcia finansowego i merytorycznego uczelni we wprowadzanych zmianach;

- równanie poziomem do najmniej zdolnych studentów poprzez wymóg, że każdy efekt ma być zdefiniowany na poziomie osiągalnym dla "przeciętnie" zdolnego studenta;

- rezygnacja z minimów programowych na rzecz opisu efektów kształcenia oznacza, że uczelnie wszak zyskały swobodę w tworzeniu nowych, autorskich kierunków studiów, ale niektórzy wyrażają obawę, czy uczelnie będą się kierowały wymogami rynku pracy, a nie "tylko ambicjami profesorów, którzy po prostu chcieliby mieć swój kierunek i swoich studentów"5.

Za przykład negatywnej oceny zmian niech posłuży następujący cytat:

KRK jest jednym z wielu - i niestety bardzo klarownym przykładem, pokazującym, jak dobre intencje mogą być wypaczone w praktycznej realizacji. (...) sporządzono niesłychanie szczegółowy i jednocześnie całkowicie oderwany od realiów szkolnictwa wyższego tabelaryczny wykaz różnych efektów kształcenia, które w większości są albo trywialnie oczywiste, albo całkowicie niesprawdzalne w praktycé ${ }^{6}$.

Padają również następujące argumenty broniące nowego ładu:

- ramy kwalifikacji wspomagają mobilność studentów i pracowników nauki oraz ułatwiają międzynarodową uznawalność dyplomów;

- efekty uczenia się opracowywane są zgodnie z potrzebami europejskiego rynku pracy;

- dzięki KRK występuje łatwość kontrolowania procedur zapewniania jakości, a tym samym wzrost jakości kształcenia;

- KRK daje możliwość akumulacji i przenoszenia osiągnięć studentów;

- KRK umożliwia udostępnienie różnorodnych, dostosowanych do potrzeb uczących się, ścieżek uczenia się i dochodzenia do pożądanych kwalifikacji;

- system KRK wspiera perspektywę uczenia się przez całe życie7

Wobec powyższych kontrowersji grupa badawcza skupiona wokół Samodzielnego Zakładu Badań nad Szkolnictwem Wyższym przy Wyższej Szkole Informatyki i Zarządzania w Rzeszowie postawiła sobie za cel przyj-

5 Z. Drozdowicz, Nadzieje na lepsze w szkolnictwie, Forum Akademickie, 2011, 3.

${ }^{6}$ T. Tadusiewicz, A. Ligęza, Wady i zalety wprowadzenia Krajowych Ram Kwalifikacji, Nauka, 2014, 1, s. 4-5.

7 A. Chłoń-Domińczak, Opracowanie zatożeń merytorycznych $i$ instytucjonalnych wdrażania KRK oraz Krajowego Rejestru Kwalifikacji dla uczenia się przez całe życie, Raport Instytutu Badań Edukacyjnych, 2012, s. 6. 
rzenie się ramom kwalifikacji $\mathrm{w}$ innych krajach europejskich $\mathrm{w}$ kontekście autonomii funkcjonujących tam uczelni. Stąd projekt zatytułowany „Praktyka wdrażania Krajowych Ram Kwalifikacji w wybranych uczelniach europejskich. Społeczno-pedagogiczne uwarunkowania implementacji zmian w programach kształcenia studentów". Projekt miał na celu przeprowadzenie analizy międzynarodowych praktyk i doświadczeń (metod, technik, narzędzi godnych naśladowania) z zakresu wdrażania ram kwalifikacji w poszczególnych krajach europejskich. Ponadto, interesujące z punktu widzenia podjętej problematyki badawczej były opinie, reakcje i spostrzeżenia kadry akademickiej na temat programów nauczania, opartych na rzeczywistych efektach uczenia się i kluczowych kompetencjach społecznych.

W ramach badań przeprowadzono wizyty studyjne w Dublin Institute of Technology, University of Huddersflied oraz w IUBH School of Business and Management w Bad Honnef. Irlandia, Wielka Brytania i Niemcy zostały wybrane nieprzypadkowo, ponieważ kraje te, obok Francji, uznawane są za wzorcowe w kwestii wdrażania ram kwalifikacji. Należy w tym miejscu podkreślić, że wyniki przeprowadzonych wywiadów pogłębionych są jedynie analizą przypadków poszczególnych uczelni, a nie reprezentatywnymi wnioskami dla systemów szkolnictwa wyższego w badanych krajach. Wywiady przeprowadzane były $\mathrm{z}$ osobami piastującymi następujące stanowiska: rektorzy, prorektorzy ds. nauczania, dziekani, dyrektorzy pionów rozwojów, przewodniczący uczelnianych komisji ds. jakości kształcenia. W ramach projektu przeprowadzono również analizę źródeł zastanych, $\mathrm{w}$ tym dokumentów przekazanych przez badane uczelnie.

\section{Swoboda kształtowania oferty dydaktycznej: przypadek I - Uniwersytet Huddersfield}

W Wielkiej Brytanii prace nad ujęciem kwalifikacji w system prowadzono już od 80. lat XX wieku, a pierwszą krajową ramę kwalifikacji zaproponowano w 1987 roku$^{8}$. Wraz z powstaniem Europejskiej Ramy Kwalifikacji (ERK) w 2008 roku w Wielkiej Brytanii podjęto starania o odniesienie istniejących ram kwalifikacji do ERK. Obecnie brytyjski system kwalifikacji tworzą trzy podsystemy: angielski (z Irlandią Północną), szkocki i walijski. Anglia, Irlandia Północna i Walia wprowadziły wspólne bądź podobne rozstrzygnięcia w dziedzinie kwalifikacji, natomiast w Szkocji obowiązują

${ }^{8}$ QAA, The framework for higher education qualifications in England, Wales and Northern Ireland. August 2008, s. 8. 
rozwiązania odrębne. Jeśli chodzi o szkolnictwo wyższe, Framework for Higher Education Qualifications jest pięciopoziomową ramą kwalifikacji zdobywanych w szkolnictwie wyższym całej Wielkiej Brytanii, z wyjątkiem Szkocji (która wykorzystuje w analogicznym celu własną Framework for QualificaQualifications of Higher Education Institutions in Scotland).

Uniwersytet Huddersfield ma status uniwersytetu od 1992 roku (wcześniej był politechniką). Studiuje tam ponad 24 tys. studentów ze 120 krajów świata9. Uniwersytet ten znany jest $\mathrm{z}$ doskonałego poziomu dydaktyki $\mathrm{w}$ takich dziedzinach, jak: elektronika, opieka społeczna, muzyka i informatyka. Uczelnia jest $\mathrm{w}$ pierwszej dziesiątce odnośnie poziomu satysfakcji studentów $^{10}$. W listopadzie 2013 roku uniwersytet zdobył nagrodę Higher Education University of the Year dziennika "The Times", a w 2012 roku nagrodę za swoją przedsiębiorczość - Higher Education award for Entrepreneurial University of the Year, także przyznaną przez dziennik „The Times”. Uczelnia plasuje się $\mathrm{w}$ pierwszej dziesiątce angielskich uniwersytetów jeśli chodzi o jakość kształcenia (2011 Sunday Times University Guide), zatrudnialność absolwentów, ofertę praktyk w przemyśle i liczbę wspieranych przez uczelnię przedsiębiorstw założonych przez studentów i absolwentów ${ }^{11}$.

Uniwersytet Huddersfield może uruchomić dowolny kierunek studiów (course), nie musi się ubiegać o zgodę instytucji zewnętrznych (np. ministerstwa). Są jednak szczegółowe procedury wewnętrzne, które mają zapewnić jakość kształcenia na nowo otwartym kierunku. Proces walidacji nowego kierunku kształcenia trwa około 1,5 roku. Każdy kierunek studiów ma swojego lidera (course leader). Każda nowa propozycja zmiany oceniana jest pod kątem ryzyka, najpierw przez zespół uczelniany, a następnie przez niezależny panel sprawdzający, złożony z: pracownika tejże uczelni, osoby z innej uczelni w Wielkiej Brytanii oraz przedstawiciela interesariuszy zewnętrznych. Podobnym procedurom poddawane są zmiany w obrębie istniejących kierunków studiów.

Kursy/moduły tworzone są przez zespół osób, kompetentnych w danej tematyce (ekspertów). Przy tworzeniu modułów są one konsultowane z interesariuszami zewnętrznymi. Każdy moduł ma swojego lidera, który współpracuje $\mathrm{z}$ innymi wykładowcami prowadzącymi dany moduł (zespoły od 2 do 6-7 osób). Liderzy poszczególnych kierunków studiów mają dość dużą swobodę w decydowaniu, jak będzie wyglądał dany kierunek. Mogą np. zdecydować, że wszystkie moduły danego kierunku będą obowiązkowe

${ }^{9}$ Annual Review 2013, https://www.hud.ac.uk/about/the-university/annualreview/ [dostęp: 10.10.2014].

10 https://www.hud.ac.uk/hr/jobs/abouttheuniversity/ [dostęp: 10.10.2014].

11 http://www.hud.ac.uk/about/the-university/ [dostęp: 10.10.2014]. 
(tak często jest na kursach na Wydziale Sztuki - Art School). Nie ma limitów odnośnie liczby przedmiotów wybieranych. Przedmioty są wybierane najczęściej spośród oferty danego wydziału (school), zazwyczaj studenci dokonują wyboru wcześniej, np. w kwietniu na semestr jesienny. Istnieją również studia typu:

- BA (Hons) CPD Programme - daje możliwość kreowania własnego programu studiów z oferty modułów uczelni; w zależności od poziomu modułów i liczby punktów zaliczeniowych można zdobyć także określony tytuł. Najczęściej opcja ta wybierana jest przez osoby pracujące, które chcą zdobyć wiedzę potrzebną im w wykonywanej pracy ${ }^{12}$;

- Combined Honours - możliwość kompilowania programu studiów z różnych zestawów modułów, np. Music $\mathcal{E}$ Politics $^{13}$.

Proporcje między pracą własną studenta a zajęciami na uczelni ustala lider modułu, bo odgórnych limitów nie ma. Podobnie $\mathrm{z}$ formami zajęć - lider modułu decyduje, czy ma to być wykład, seminar czy lecture ${ }^{14}$. Istnieje tzw. subject benchmark statement dla danego obszaru kształcenia - np. general business and management ${ }^{15}$, opracowany przez QQA, w którym opisane są ogólnie efekty kształcenia, metody weryfikacji, sylwetka absolwenta. Uczelnia ma wykazać, w jaki sposób efekty kształcenia wpisują się w odpowiednie elementy sylwetki absolwenta - przygotowuje się tzw. mapping document.

Uczelnia jest poddawana zewnętrznej ocenie jakości kształcenia cyklicznie - co 5 lat. Ocena przeprowadzana jest przez QAA. Negatywny wynik nie oznacza zamknięcia danego kierunku czy wydziału - uczelniom zależy jednak bardzo na pozytywnym wyniku oceny, gdyż wpływa to na wizerunek uczelni. Jak wspomniała jedna $\mathrm{z}$ respondentek, negatywne wyniki oceny zdarzają się rzadko, a chronią przed nimi odpowiednie procedury. Ostatnia zewnętrzna kontrola jakości na uniwersytecie w Huddersfield miała miejsce w marcu 2010 roku i uczelnia otrzymała najwyższą ocenę. Zwrócono uwagę

12 http://www.hud.ac.uk/courses/part-time/undergraduate/continuing-professionaldevelopment-ba-hons/ [dostęp: 10.10.2014].

${ }^{13}$ http://www.hud.ac.uk/courses/full-time/combined-honours-ba-bsc-hons/ [dostęp: 10.10.2014].

${ }^{14} \mathrm{~W}$ toku studiów realizowane są trzy formy prowadzenia zajęć: wykład (lecture), ćwiczenia (tutorial) oraz seminaria (seminar). Różnice pomiędzy tymi formami mogą być rozpatrywane na dwa sposoby: różnice $\mathrm{w}$ metodach nauczania oraz różnice w liczbie studentów (lecture cały rok, tutorial - najmniejsza grupa). Różnice między tutorial a seminar są niewielkie - tutorial trwa zazwyczaj 1 godzinę, seminar - 2 godz., grupa tutorialowa to najczęściej około 25 osób (ale może być nawet 60 - dużo zależy od rozmiaru sali!), grupa seminaryjna - 35-40 osób. Zazwyczaj uwzględnia się sugestie prowadzących zajęcia co do tego jaką formę mają mieć zajęcia.

${ }^{15}$ http://www.qaa.ac.uk/en/Publications/Documents/Subject-benchmark-statementGeneral-business-and-management.pdf [dostęp: 10.10.2014]. 
na użycie Mapy Strategicznej (Strategy Map) do wprowadzania i koordynacji zmian na terenie uczelni, proaktywną postawę działu informatycznego i biblioteki (Computing and Library Services), wszechstronne i systematyczne wsparcie oferowane studentom oraz wkład w zapewnianie jakości poprzez różne sposoby dostrzegania osiągnięć studentów i pracowników ${ }^{16}$.

Oprócz zewnętrznej oceny jakości kształcenia, każdy kierunek studiów jest poddawany wewnętrznej ocenie co 5 lat (kiedyś takie wewnętrzne kontrole także przeprowadzała QAA). W komisji znajdują się osoby z innej uczelni, innego wydziału danej uczelni, przedstawiciel samorządu studenckiego, osoba z otoczenia biznesowego. Każdy moduł ma tzw. zewnętrznego egzaminatora (external examiner) - osobę $\mathrm{z}$ innej instytucji, konsultującą i zatwierdzającą zawartość modułu, metody oceny oraz wszelkie zmiany w obrębie modułu.

Uczelnie dużą wagę przykładają do wewnętrznych procedur zapewniania jakości. Istnieją specjalne jednostki ds. zapewniania jakości, ich ulokowanie $\mathrm{w}$ strukturze uczelni może być różne, na uniwersytecie w Huddersfield jest to Quality Assurance Team, będąca częścią Registry17, zatrudniająca obecnie 5 osób. Istnieje również Quality Assurance Procedures for Taught Courses ${ }^{18}$ - swoista „Księga jakości”.

Podsumowując, $\mathrm{w}$ brytyjskim systemie szkolnictwa wyższego uczelnie mają dowolność w tworzeniu nowych kierunków studiów, ale dysponują także bardzo szczegółowymi i czasochłonnymi procedurami zapewniania jakości. Spotykają się nieraz z niechęcią nauczycieli akademickich - z jednej strony, pozwalają one na jasność i przejrzystość, z drugiej - wydłużają pewne procesy. Niektórzy twierdzą, że długie i skomplikowane procedury zabijają kreatywność: „niektórzy pracownicy postrzegają to jako barierę do wychodzenia z nowymi inicjatywami, ponieważ to oznacza bardzo dużo pracy i przygotowań, ale większość rozumie, dlaczego te procedury są potrzebne, dostrzega korzyści ze standaryzacji pewnych rzeczy"19. Procedury te są $\mathrm{w}$ istocie liczne i obejmują szeroki zakres obszarów związanych w kształceniem, zostawiają jednak pewną swobodę dotyczącą zawartości modułu, jego formy i szczegółowych metod oceniania.

16 https://www.hud.ac.uk/about/the-university/quality-assurance-agency/ [dostęp: 10.10.2014].

17 Jednostka w rodzaju Działu Nauczania/Kształcenia współpracuje z Prorektorem odpowiedzialnym za kwestie związane z dydaktyką.

18 http://www.hud.ac.uk/registry/regulationsandpolicies/qa/ [dostęp: 10.10.2014]. snych.

${ }_{19}$ Cytat pochodzi z wywiadów pogłębionych przeprowadzonych $\mathrm{w}$ ramach badań wła- 


\section{Wysokie standardy kształcenia i kontakty z pracodawcami: przypadek II - Uniwersytet w Bad Honnef}

Proces tworzenia niemieckiego systemu jakości w obszarze szkolnictwa wyższego trwa nieprzerwanie od 90. lat XX wieku. Obecny kształt Krajowej Struktury Kwalifikacji (Qualifikationsrahmen für Deutsche Hochschulabschlüsse) został uzgodniony i wdrożony przez Konferencję Rektorów Niemieckich (Hochschulrektorenkonferenz), Federalne Ministerstwo Edukacji i Nauki (Bundesministerium für Bildung und Forschung, BMBF) oraz Stałą Konferencję Ministrów Edukacji i Kultury Landów (Kulturminister-Konferenz, KMK) 21 kwietnia 2005 roku $^{20}$. Struktura studiów została natomiast określona w ramowej ustawie o szkolnictwie wyższym z 1998 roku (Hochschulrahmengesetz, HRG), znowelizowanej w 2005 roku o zasady systemu bolońskiego, po konferencjach w Bergen i Berlinie. Wspomniana ustawa przewiduje możliwość prowadzenia studiów licencjackich/inżynierskich, kończących się tytułem Bachelor i studiów magisterskich, kończących się tytułem Master oraz określa ich minimalny czas trwania. Trójstopniowa struktura studiów funkcjonuje na uniwersytetach i politechnikach od 1998 roku. Równolegle współistnieją także studia jednolite, realizowane na takich kierunkach, jak: medycyna, weterynaria, stomatologia.

Uniwersytet w Bad Honnef to uczelnia prywatna, założona w 2000 roku. IUBH jest pierwszą uczelnią w Niemczech, w której wszystkie zajęcia prowadzone są w języku angielskim. Obecnie kształci ponad 3300 studentów na 6 kierunkach I stopnia oraz 4 kierunkach II stopnia. Umiędzynarodowienie uczelni oraz koncentracja na praktycznym modelu kształcenia sprawiają, że uczelnia uznawana jest za prestiżową i elitarną. Świadczą o tym wysokie pozycje zajmowane $\mathrm{w}$ krajowych $\mathrm{i}$ międzynarodowych rankingach, certyfikatach i akredytacjach, w tym: Centre for Higher Education University Rankings, United Nations' World Tourism Organisation, The Leading Hotel Schools of the World, The German Council of Science and Humanities. W marcu 2014 roku pięć programów studiów realizowanych w IUBH zostało nagrodzonych FIBAA Premium Seal za osiągnięcie bardzo wysokich standardów jakości kształcenia ${ }^{21}$.

${ }^{20}$ Qualifikationsrahmen für Deutsche Hochschulabschlüsse, BMBF, (2005):

http://www.kmk.org/fileadmin/veroeffentlichungen_beschluesse/2005/2005_04_21-

Qualifikationsrahmen-HS-Abschluesse.pdf.

21 IUBH and FIBAA celebrate together the excellent Quality of five Study Programmes (29/04/2014): http://www.fibaa.org/en/news-alt/details/date/2014/04/29/iubh-und-fibaafeiern-gemeinsam-die-exzellente-qualitaet-von-fuenf-studiengaengen-29042014.html. 
Proces akredytacji na uczelniach wyższych w Niemczech przebiega w sposób pośredni, mianowicie centralna agencja - Rada Akredytacyjna (Akkreditierungsratm, $\mathrm{AR}^{22}$ ) przyznaje akredytacje krajowym i zagranicznym instytucjom akredytującym ${ }^{23}$, które $\mathrm{z}$ kolei odpowiedzialne są za akredytacje programów studiów ${ }^{24}$. Uczelnia ma dowolność w wyborze agencji akredytującej. Uniwersytet w Bad Honnef posiada akredytację FIBAA (Foundation for International Business Administration Accreditation)25. Jest to międzynarodowa organizacja promująca jakość oraz przejrzystość w dziedzinie edukacji i nauki poprzez przyznawanie certyfikatów jakości do programów edukacyjnych i instytucji edukacyjnych $\mathrm{w}$ obszarze szkolnictwa wyższego oraz dalszego rozwoju zawodowego. Współpracując $w$ ramach organów międzynarodowych, FIBAA zwiększa porównywalność standardów jakości i procedur zarządzania jakością ${ }^{26}$.

Uchwalona w lutym 2005 roku ustawa o utworzeniu „Fundacji ds. Akredytacji Studiów w Niemczech" stworzyła nową podstawę prawną procesu akredytacji ${ }^{27}$. Akredytacja ma zapewnić przestrzeganie standardów dotyczących treści kształcenia; obejmuje ona ocenę koncepcji studiów, możliwości realizacji różnych zajęć do wyboru i jakości nauczania oraz ocenę adekwatności pod kątem wymogów zawodowych i rozwiązań służących zapewnieniu równych szans kobietom i mężczyznom. Akredytacja stanowi procedurę zewnętrznego zapewniania jakości. Opiera się ona na zasadzie "oceny środowiskowej" (peer review). Oprócz nauczycieli akademickich uczestniczą $\mathrm{w}$ niej studenci, przedstawiciele partnerów społecznych oraz eksperci zagraniczni. W procedurach akredytacji nie uczestniczą bezpośrednio władze państwowe ${ }^{28}$.

22 AR udzieliło akredytacji 11 agencjom akredytującym:

http://www.akkreditierungsrat.de/index.php?id=agenturen\&L=1.

${ }^{23}$ Regeln des Akkreditierungsrates für die Akkreditierung von Agenturen. Beschluss des Akkreditierungsrates vom 08.12.2009, Drs. AR 91/2009.

24 Regeln des Akkreditierungsrates für die Akkreditierung von Studiengängen. Beschluss des Akkreditierungsrates vom 08.12.2009, Drs. AR 93/2009.

${ }^{25}$ FIBAA została wpisana do Europejskiego Rejestru Zapewniania Jakości (EQAR):

https://www.eqar.eu/register/detailpage.html?tx_pxdeqar_pi1[cid]=22\&tx_pxdeqar_pi1[bac $\mathrm{k}][$ pid] $=6$.

${ }^{26}$ FIBAA: http://www.fibaa.org/en/welcome-page.html.

${ }^{27}$ Establishment of a Foundation for the Accreditation of Study Courses in Germany: http://www.akkreditierungsrat.de/fileadmin/Seiteninhalte/Stiftung/recht.Grundlagen/Fou ndation_Law.pdf.

28 Więcej: The Education System in the Federal Republic of Germany 2011/2012. A description of the responsibilities, structures and developments in education policy for the exchange of information in Europe, s. 231: http://www.kmk.org/fileadmin/doc/Dokumentation/Bildungswesen_en_pdfs/ dossier_en_ebook.pdf. 
Oficjalnie obowiązuje zasada, iż każdy program studiów powinien być akredytowany. $\mathrm{W}$ rzeczywistości jednak akredytacje ma zaledwie połowa programów.

Fundamentalnym wymogiem otrzymania akredytacji jest posiadanie wewnętrznego systemu oceny jakości kształcenia ${ }^{29}$. W przypadku IUBH system ten polega na cyklicznym przeprowadzaniu elektronicznych ankiet wśród studentów. Studenci wówczas oceniają jakość kształcenia poprzez: satysfakcje z zajęć, przygotowanie wykładowcy, umiejętności językowe, umiejętności motywacji studentów do pracy podczas zajęć, dostępność wykładowcy - obecność na zajęciach/konsultacjach, satysfakcję końcową z kursu w skali od 0 do $100 \%$. Ponadto organizowane są kursy doszkalające dla kadry dydaktycznej.

Poza tym, Biuro Karier co 2 lata przeprowadza ankietę wśród absolwentów IUBH, która dotyczy satysfakcji ze studiów w IUBH, możliwych ulepszeń/udoskonaleń/wskazówek, które można by wprowadzić na uczelni.

W związku z faktem, że studenci muszą wykazywać się odpowiednim poziomem języka angielskiego, aby rozpocząć studia, następuje weryfikacja posiadanych umiejętności poprzez okazanie certyfikatu TOEFL (80 punktów) lub IELTS (na poziomie 6.0). Uczelnia dla osób nieanglojęzycznych nie prowadzi kursów doszkalających z tego języka.

Zewnętrzna kontrola jakości przeprowadzana jest przez FIBAA po 3-5 latach, natomiast $\mathrm{w}$ przypadku programu studiów oraz $\mathrm{w}$ odniesieniu do całej uczelni - po 7-10 latach. W momencie nieuzyskania pozytywnego wyniku procesu akredytacji uczelnia traci prawo do prowadzenia danego kierunku studiów. W praktyce sytuacja taka rzadko ma miejsce $\mathrm{z}$ uwagi na fakt, iż instytucje akredytujące właściwie realizują swą rolę doradczą.

Uczelnia ma dużą swobodę $\mathrm{w}$ tworzeniu nowych kierunków, jak również $\mathrm{w}$ przygotowywaniu poszczególnych kart przedmiotów. Odgórnie ustalane są jedynie ramy i procedury, które współgrają z wymaganiami uniwersyteckimi i zarazem są zgodne z ESG ${ }^{30}$.

Proces tworzenia nowego programu studiów przebiega według następującego schematu:

- dyrektor programu (odpowiednik polskiego dziekana) bada popyt na dany program, np. z użyciem Google AdWords, który pokazuje, czy studen-

${ }^{29}$ European Study Reform - Recommendation of the 15th General Meeting of the German Rectors' Conference (HRK) on 19 November 2013 in Karlsruhe, 19 November 2013, s. 18:

http://www.hrk.de/uploads/tx_szconvention/HRK_MV_15_Empfehlung_Europaeische_Stu dienreform_EN_01.pdf.

30 Standards and Guidelines for Quality Assurance in the European Higher Education Area: http://www.enqa.eu/files/ESG_3edition\%20\%282\%29.pdf. 
ci poszukują tego typu programów oraz na podstawie rozmów ze studentami, absolwentami oraz pracodawcami;

- dyrektor programu rozmawia z partnerami z biznesu - aranżowane są warsztaty/spotkania z ekspertami z branży odnośnie potencjalnego programu, pracodawcy udzielają wskazówek, czego będą oczekiwać od absolwentów danego programu studiów;

- następnie odbywają się rozmowy na konkretnym wydziale, gdzie zapada decyzja, czy uczelnia spełnia wymogi formalne do otwarcia nowego programu, tj. trwa analiza, czy uzyska akredytację FIBAA;

- jeśli decyzja jest pozytywna, dyrektor programu oraz odpowiedzialny prorektor przygotowują projekt programu, który kierowany jest do Rektoratu;

- na końcu następuje opracowanie programu nauczania oraz księgi programu (kierunku).

Jako że uczelnia koncentruje się na zapewnianiu kadry dla sektora usług, udział interesariuszy zewnętrznych $\mathrm{w}$ procesie tworzenia/przeobrażania kierunków jest znaczny i zarazem niezbędny ${ }^{31}$. W skład grup roboczych wchodzą przedstawiciele uczelni, przedsiębiorcy oraz studenci. Zaangażowanie studentów $\mathrm{w}$ prace zespołów ds. jakości jest dobrowolne po pozytywnym przejściu procesu rekrutacji i szkolenia ${ }^{32}$. Aktywne uczestnictwo przedstawicieli biznesu wiąże się z prezentacją wymagań/umiejętności, punktowanych $\mathrm{w}$ procesie rekrutacji, jak również stanowi okazję do wymiany poglądów oraz udzielenia wskazówek związanych z istniejącymi programami studiów. Dzięki cennym wskazówkom program studiów spełnia oczekiwania pracodawców na rynku pracy. Przykładem może być realizowany w IUBH program Dual-Studies ${ }^{33}$.

Uczelnia stale monitoruje losy absolwentów. Z badań wynika, że 75\% absolwentów pracuje w korporacjach międzynarodowych, a $20 \%$ na stanowiskach kierowniczych. Co więcej, 86\% absolwentów znajduje zatrudnienie w ciągu 3. miesięcy od ukończenia studiów ${ }^{34}$.

Podsumowując, ramy kwalifikacji w Niemczech są traktowane jako swoista instrukcja dla kadry dydaktycznej:

Jeśli jesteś dobrym pisarzem nawet nie potrzebujesz pytań naprowadzających, po prostu wiesz co masz pisać. Co bystrzy nauczyciele potrafią. (...) Sądzę więc, że dla

${ }^{31}$ European Study Reform - Recommendation of the 15th General Meeting of the German Rectors' Conference (HRK) on 19 November 2013 in Karlsruhe, 19 November 2013:

http://www.hrk.de/uploads/tx_szconvention/HRK_MV_15_Empfehlung_Europaeische_Stu dienreform_EN_01.pdf, s. 14-15, 18-19.

32 Studentischer Akkreditierungspool: http://www.studentischer-pool.de/.

${ }^{33}$ IUBH School of Business and Management: http://www.iubh.de/en/.

${ }^{34}$ Informacje pochodzą z wywiadu pogłębionego. 
mniej bystrych wykładowców KRK jest pomocne, ponieważ wiedzą, jakie kwestie mają poruszyć podczas zajęć ze studentami ${ }^{35}$.

Uczelnie mają dość znaczy stopień swobody w tworzeniu nowych kierunków. Ponadto, ścisła współpraca $\mathrm{z}$ biznesem $\mathrm{w}$ procesie powstawania nowych programów studiów pozwala na ich ciągłe doskonalenie i dostosowywanie do zmieniających się wymagań rynkowych. Efektem wspomnianych działań jest bardzo wysoki wskaźnik zatrudnienia absolwentów.

\section{Omnipotentna rola praktyków w dydaktyce: przypadek III: Dublin Institute of Technology}

W 1999 roku władze Irlandii podpisały tzw. "Qualifications Act", czyli dokument, umożliwiający wdrażanie Krajowych Ram Kwalifikacji (NFQ National Framework of Qualifications). Na mocy tego dokumentu w 2001 roku utworzono The National Qualifications Authority of Ireland, którego głównym zadaniem był rozwój i wdrożenie ram, zbudowanie spójnego systemu umożliwiającego porównanie i uznawanie kompetencji oraz promocja i ułatwienie przenoszenia się uczącego z jednego poziomu na drugi, niezależnie od typu uczelni. Oficjalne wdrożenie NFQ nastąpiło w 2003 roku. Obecnie uważa się, iż Irlandia jest krajem, w którym poziom funkcjonowania krajowych ram kwalifikacji jest najbardziej zaawansowany. Ponadto, irlandzka NFQ jest Ramą kompletną (wszechogarniającą), obejmującą wszystkie sektory i typy kształcenia ${ }^{36}$.

Dublin Institute of Technology (DIT) to uczelnia publiczna, kształcąca około 20 tys. studentów na 122 kierunkach, z prawem do nadawania stopnia naukowego doktora. $\mathrm{W}$ odróżnieniu od polskich uczelni, w uczelniach irlandzkich, w tym DIT, obowiązuje system modułowy, to jest bloki tematyczne, realizowane za pomocą różnych form (np. wykład, projekt, e-learning), który po wejściu Krajowych Ram Kwalifikacji zastąpił tradycyjne przedmioty. W DIT każdy moduł jest realizowany w ciągu jednego semestru (w wyjątkowych przypadkach realizowany jest $\mathrm{w}$ ramach dwóch semestrów). Moduły mają zazwyczaj 5, 10 lub 15 punktów ECTS, gdzie 1ECTS = 20h. Wlicza się $\mathrm{w}$ to zarówno zajęcia, jak i pracę własną studenta. W przypadku niezaliczenia danego modułu, student ma możliwość jego poprawy snych.

35 Cytat pochodzi z wywiadów pogłębionych przeprowadzonych w ramach badań wła-

${ }^{36}$ G. Bryda i in., Analiza opisujaca Krajowe Ramy Kwalifikacji w Europejskim Obszarze Szkolnictwa Wyższego. Część druga zamówienia, http://www.nauka.gov.pl. [dostęp: 29.08.2014]. 
dopiero podczas kolejnej sesji egzaminacyjnej, czyli za rok. Wynika to z rocznego systemu zaliczania studiów, opartego na punktach ECTS. Dla każdego programu określona jest liczba modułów, a dla każdego modułu tworzona jest karta modułu (znacznie prostsza w swej formie w porównaniu z polskimi kartami przedmiotów). Dzięki takiemu podejściu znacznie łatwiejsze jest tworzenie nowych programów studiów. Samo podejście do tworzenia nowej oferty dydaktycznej, tj. programów studiów jest bardzo podobne do realiów polskich. Pierwszy krok stanowi opisanie sylwetki absolwenta, natomiast kolejny odpowiedź na pytanie: jakie efekty kształcenia odpowiadają tej sylwetce? Następnie dokonywana jest analiza modułów, które mają przyczynić się do uzyskania odpowiednich efektów kształcenia. Ostatnim krokiem jest dobór odpowiednich metod oceny poszczególnych efektów. W porównaniu z polskimi programami, programy studiów w DIT są bardzo uproszczone. Zawierają jedynie informacje na temat: nazw realizowanych modułów, liczby punktów transferowych przypadających na poszczególne moduły, czasu trwania semestru, przedmiotów do wyboru. Kreując nowe programy studiów, uczelnie irlandzkie dużą wage przywiązują również do dopasowania oferty kształcenia do potrzeb rynku pracy. Wszystkie programy tworzone są przy współpracy z otoczeniem biznesowym (na podstawie formalnych porozumień). Na przykład, przy opracowaniu programów studiów na ścieżce Turystyka i zarządzanie gościnnościa, DIT współpracuje z takimi firmami, jak: Starbucks, Aer Lingus, czy Guinness. Tak zwani praktycy są włączani w proces dydaktyczny i 50\% zajęć na studiach magisterskich prowadzonych jest przez takie osoby. Współpraca z interesariuszami zewnętrznymi jest na tyle ścisła, iż przedstawiciele świata biznesu biorą udział również $\mathrm{w}$ postępowaniach rekrutacyjnych nowych pracowników naukowo-dydaktycznych. Istotne dla uczelni są również kwestie dotyczące badania losów absolwentów. Monitorowanie losów absolwentów w Irlandii odbywa się na poziome krajowym, z wykorzystaniem wywiadów telefonicznych. Są to badania ilościowe, mające na celu zebranie informacji na temat, jak potoczyła się kariera absolwentów i jak im w tym pomógł dyplom danej uczelni. Przyglądając się procesowi dydaktycznemu w DIT, należy zauważyć, że fizyczna obecność studentów na większości przedmiotów nie jest obowiązkowa - panuje idea self-directed learning, czyli nauczania nakierowanego na własną kontrolę (oczywiście są wyjątki, jak np. laboratoria, gdzie próg wymaganej frekwencji stanowi minimum 75-80\% zajęć). Ponadto, około $20 \%$ każdego z programów ma charakter elastyczny, tzn. studenci sami mogą dokonać wyboru, na jakie zajęcia chcą uczęszczać. W przypadku nauczycieli akademickich, nie ma formalnych zapisów mówiących, iż osoby posiadające stopień magistra nie mogą prowadzić zajęć 
w formie wykładowej (w DIT większość wykładowców posiadających stopień magistra prowadzi wykłady). Interesującym sposobem motywowania wykładowców do dbałości o jakość swoich zajęć są stypendia dydaktyczne (teaching awards), przyznawane za wybitne osiągnięcia dydaktyczne.

Problem, z jakim obecnie spotykamy się w polskich uczelniach dotyczący zaliczania społecznych efektów kształcenia. W DIT rozwiązywany jest on poprzez: 1) odbywanie praktyk studenckich testujących miękkie kompetencje; 2) udział studentów w praktykach i stażach, za które dostają referencje od pracodawcy; 3) promowanie idei wolontariatu (ponad $80 \%$ studentów DIT włącza się w jakąś formę wolontariatu podczas studiów, a $20 \%$ najprężniej działających na tym polu studentów uzyskuje dodatkowe punkty ECTS) oraz 4) doświadczenie, jakie studenci nabywają poprzez działalność w klubach i stowarzyszeniach ${ }^{37}$.

Jak wynika z powyższego, zaliczenie społecznych kompetencji, wynikających z programów kształcenia, w głównej mierze ma miejsce poza formalną ścieżką kształcenia.

Irlandzkie uczelnie, w odróżnieniu od Polski, nie są tak ściśle kontrolowane przez państwowych urzędników. Zewnętrzne oceny dokonywane są co 5-6 lat poprzez Quality and Qualifications Ireland, która kontroluje jedynie wybrane losowo programy. Niemniej jednak, celem dbania o jakość kształcenia, uczelnie irlandzkie przeprowadzają indywidualnie, raz na 5 lat, wewnętrzne oceny (w DIT odpowiedzialna za kontrole jest Komisja ds. Zapewniania Jakości Akademickiej - Academic Quality Assurance Committee), podczas których główny nacisk kładziony jest na wdrażanie procedur zapewniania jakości. W procesie tym bardzo często udział biorą studenci oraz zewnętrzni egzaminatorzy z partnerskich uczelni z Wielkiej Brytanii i USA. Na bazie wyników tworzony jest tzw. naprawczy plan działania, rozpisany najczęściej na 12 miesięcy, po których przeprowadzana jest ponowna kontrola. Innym systemem wspierającym jakość jest tzw. teaching and learning fellowships, czyli program, w którym dydaktycy konkurują o środki na badania dotyczące uczenia się i nauczania, mające na uwadze polepszenie jakości nauczania studentów $\mathrm{w}$ przyszłości.

Podsumowując, irlandzki system szkolnictwa wyższego jest najbardziej zaawansowany - ma ponad dziesięcioletnie doświadczenie $\mathrm{w}$ pracy $\mathrm{z}$ ramami kwalifikacji. W tym okresie NFQ ulegały wielu przemianom, które

37 W DIT działa około 70 towarzystw studenckich, których działalność obejmuje dziedziny związane z oferowanymi kierunkami kształcenia, ale także np. sztuki teatralne, religie, język migowy, media studenckie. Towarzystwa są prowadzone przez studentów dla studentów http://www.dit.ie/societies/ 
miały na celu uproszczenie istniejących rozwiązań i dostosowanie ich do potrzeb wszystkich interesariuszy. Zachodzące zmiany początkowo były przyjmowane przez środowisko akademickie $\mathrm{z}$ dużą dozą ostrożności. Obecnie większość osób podkreśla pozytywne aspekty właściwie prowadzonego systemu zapewniania jakości, pojmowanego jako proces dążący do udoskonalenia istniejących rozwiązań.

\section{Podsumowanie:}

\section{dobre rozwiązania wynikające $\mathrm{z}$ doświadczeń badanych uczelni}

Po przeanalizowaniu systemów kształcenia w Wielkiej Brytanii, Niemczech i Irlandii oraz wizytach studyjnych odbytych na uczelniach $\mathrm{w}$ tych krajach, nasuwa się kilka refleksji i propozycji korekt w kształceniu na polskich uczelniach. Potrzebna jest jednak tutaj pewna uwaga natury ogólnej: celem badań było przede wszystkim uchwycenie specyfiki funkcjonowania "narodowych ram kwalifikacji”, jednak w wyniku podjętych dociekań otrzymaliśmy znacznie szerszą wiedzę. Chociażby wiedzę na temat sposobu prowadzenia zajęć, relacji student-wykładowca, kształtowania polityki kadrowej, czy systemu zapewniania jakości. Poniższe wnioski będą więc dotyczyć materii znacznie szerszej niż sam proces implementacji KRK w danym kraju. I jeszcze uwaga szczegółowa, niektóre $\mathrm{z}$ tych rozwiązań $\mathrm{w}$ polskich uczelniach już funkcjonują, jednak nie są standardem. Co więc dla nas może być inspirujące?

- W badanych uczelniach Wielkiej Brytanii, Niemiec i Irlandii tradycyjne przedmioty zastąpione zostały modułami, tj. blokami tematycznymi, realizowanymi za pomocą różnych form (np. wykładu, projektu, e-learningu). Nauczyciel akademicki nie ma narzuconej odgórnie (np. poprzez kartę przedmiotu) formy prowadzenia zajęć - dobiera ją na bieżąco, zgodnie z własnym doświadczeniem dydaktycznym. W praktyce oznacza to, że $\mathrm{w}$ ramach jednego spotkania część zajęć może poprowadzić $\mathrm{w}$ formie wykładu podawczego, część - $\mathrm{w}$ formie burzy mózgów, część - w formie debaty itp. To wykładowca decyduje, jaką formę prowadzenia zajęć w danym momencie należy przyjąć.

- Karty modułów są dość elastyczne, nie narzucają wykładowcom ani form prowadzenia zajęć, ani zasad oceny wiedzy, kompetencji i umiejętności studentów. Są pewnym drogowskazem, propozycją. Ponadto, każdy prowadzący co roku nanosi zmiany w karcie, bazując na minionych doświad- 
czeniach. Sama karta przedmiotu - w ramach modułów - też pozostawia nauczycielowi akademickiemu pewien stopień swobody - np. karta w IUBH School of Business and Management w Bad Honnef określa zakres tematyczny przedmiotu, cele, metody aktywizujące studentów oraz sposób zaliczenia przedmiotu.

- Zaliczenie społecznych kompetencji - czyli to, z czym w Polsce mamy największy problem - wynikających z programów kształcenia może mieć miejsce poza formalną ścieżką kształcenia, np. poprzez działalność wolontariacką czy zaangażowanie studentów $\mathrm{w}$ funkcjonowanie uczelnianych organizacji i klubów. Takie rozwiązanie stosuje się np. w Dublin Institute of Technology.

- We wszystkich badanych uczelniach kładzie się nacisk na stosowanie metod aktywizujących ( $\mathrm{w}$ badanej niemieckiej uczelni stanowią one ponad $50 \%$ metod stosowanych podczas zajęć).

- Uczelnia może uruchomić dowolny kierunek studiów, nie musi się ubiegać o zgodę, np. ministerstwa. Są jednak szczegółowe procedury wewnętrzne, które mają zapewnić jakość kształcenia na nowo otwartym kierunku (to rozwiązanie $\mathrm{z}$ Wielkiej Brytanii). Jak się dowiedzieliśmy w University of Huddersfield, uczelnia tworzy nowy kierunek analizując potrzeby otoczenia, dostępne zasoby dydaktyczne i infrastrukturalne oraz możliwe nawiązanie współpracy dotyczącej kształcenia z przedsiębiorstwami i innymi interesariuszami. Uczelnia ma więc swoistą autonomię programową, a kontrolowana jest $\mathrm{z}$ efektywności działania wewnętrznego systemu zapewniania jakości. Procedury stosowane w zapewnianiu jakości są liczne i obejmują szeroki zakres obszarów związanych w kształceniem, zostawiając jednak pewną swobodę dotyczącą zawartości modułu, czy szczegółowych metod oceniania.

- Stopień naukowy nie jest wyznacznikiem przydatności dydaktycznej. W badanych uczelniach Irlandii i Wielkiej Brytanii bardzo duży udział w dydaktyce mają praktycy. Wykład prowadzony przez magistra-praktyka nie stanowi problemu (w DIT to standard).

Należy oczywiście zdać sobie sprawę, iż badania zostały przeprowadzone $\mathrm{w}$ uczelniach o bardzo mocnym nachyleniu praktycznym. Inne wnioski mogły by się pojawić, gdybyśmy analizowali wielkie uniwersytety $\mathrm{w}$ tych krajach. Jednakże, wydaje się, iż większość opisanych w artykule spostrzeżeń, czy dobrych praktyk, może być rozpatrywanych jako inspiracja do kształtowania w naszym kraju oferty tzw. kierunków o profilu praktycznym. 


\section{BIBLIOGRAFIA}

Bryda G., Bugaj J., Domańska M., Frankowicz M., Godzwon Z., Mirecka J., Urbanik J., Analiza opisująca Krajowe Ramy Kwalifikacji w Europejskim Obszarze Szkolnictwa Wyższego. Część druga zamówienia, http:/ / www.nauka.gov.pl. [dostęp: 29.08.2014].

Chłon-Domińczak A., Opracowanie założeń merytorycznych $i$ instytucjonalnych wdrażania KRK oraz Krajowego Rejestru Kwalifikacji dla uczenia się przez całe życie, Instytut Badań Edukacyjnych, 2012.

Chmielecka E., Marciniak Z., Kraśniewski A., Krajowe ramy kwalifikacji dla polskiego szkolnictwa wyższego, [w:] Ramy kwalifikacji dla szkolnictwa wyższego jako narzędzie poprawy jakości kształcenia, Ministerstwo Nauki i Szkolnictwa Wyższego, Warszawa 2010.

Choromańska J., Europejski Obszar Szkolnictwa Wyższego, www.uniaeuropejska.org, 2013.

Drozdowicz Z., Nadzieje na lepsze w szkolnictwie, Forum Akademickie, 2011, 3.

DzU 2011, 253, 1520.

European Study Reform - Recommendation of the 15th General Meeting of the German Rectors' Conference (HRK) on 19 November 2013 in Karlsruhe, 19 November 2013: http://www.hrk.de/uploads/tx_szconvention/HRK_MV_15_Empfehlung_Europae ische_Studienreform_EN_01.pdf.

Establishment of a Foundation for the Accreditation of Study Courses in Germany: http://www.akkreditierungsrat.de/fileadmin/Seiteninhalte/Stiftung/recht.Grundl agen/Foundation_Law.pdf

Pawlikowski J.M., Wdrażanie programów kształcenia opracowanych zgodnie z założeniami KRK dla szkolnictwa wyższego, Seminarium bolońskie, Łódź 25.03.2013, http://eksper cibolonscy.org.pl/sites/ekspercibolonscy.org.pl/files/proces_ksztalcenia_a_ krk_jp_250313.pdf.

http://www.qaa.ac.uk/about-us

http://www.qaa.ac.uk/assuring-standards-and-quality/the-quality-code

http://www.hud.ac.uk/courses/part-time/undergraduate/continuing-professional-

development-ba-hons/

http://www.hud.ac.uk/courses/full-time/combined-honours-ba-bsc-hons/

https://www.hud.ac.uk/about/the-university/quality-assurance-agency/

http://www.qaa.ac.uk/en/Publications/Documents/Subject-benchmark-statement-

General-business-and-management.pdf

http://www.hud.ac.uk/registry/regulationsandpolicies/qa/

https://www.hud.ac.uk/about/the-university/annualreview/

https://www.eqar.eu/register/detailpage.html?tx_pxdeqar_pi1[cid]=22\&tx_pxdeqar_pi $1[$ back $][$ pid $]=6$.

http://www.fibaa.org/en/welcome-page.html

http://www.iubh.de/en/

http://www.akkreditierungsrat.de/index.php?id=agenturen\&L=

Regeln des Akkreditierungsrates für die Akkreditierung von Agenturen. Beschluss des Akkreditierungsrates vom 08.12.2009, Drs. AR 91/2009.

Regeln des Akkreditierungsrates für die Akkreditierung von Studiengängen. Beschluss des Akkreditierungsrates vom 08.12.2009, Drs. AR 93/2009.

Solarzyk-Szewc H., Walidacja kompetencji społecznych w kontekście Krajowych Ram Kwalifikacji dla Szkolnictwa Wyższego, E-mentor, 2013, 5(52).

Standards and Guidelines for Quality Assurance in the European Higher Education Area: http:/ / www.enqa.eu/files/ESG_3edition \%20\%282\%29.pdf. 
Studentischer Akkreditierungspool: http://www.studentischer-pool.de/.

Tadusiewicz T., Ligęza A., Wady i zalety wprowadzenia Krajowych Ram Kwalifikacji, Nauka, 2014, 1.

The Education System in the Federal Republic of Germany 2011/2012. A description of the responsibilities, structures and developments in education policy for the exchange of information in Europe.

Wroczyńska A., Jak wprowadzaliśmy KRK na Uniwersytecie Warszawskim, Forum Akademickie, 2013, 07-08.

QAA, The framework for higher education qualifications in England, Wales and Northern Ireland, August 2008.

Qualifikationsrahmen für Deutsche Hochschulabschlüsse, BMBF, 2005: http://www.kmk.org/ fileadmin/veroeffentlichungen_beschluesse/2005/2005_04_21-

Qualifikationsrahmen-HS-Abschluesse.pdf. 